Tropical Journal of Pharmaceutical Research September 2015; 14 (9): 1635-1641

ISSN: 1596-5996 (print); 1596-9827 (electronic)

(C) Pharmacotherapy Group, Faculty of Pharmacy, University of Benin, Benin City, 300001 Nigeria.

All rights reserved.

Available online at http://www.tjpr.org

Original Research Article

http://dx.doi.org/10.4314/tjpr.v14i9.13

\title{
Effects of Aqueous Extract of Unpolished Dark Purple Glutinous Rice, Var Luem Pua, on ROS in SK-N-SH Cells and Scopolamine-induced Memory Deficit in Mice
}

\author{
Supawadee Srisuwan', Tarinee Arkaravichien', Sugunya Mahatheeranont ${ }^{2}$, \\ Pakawan Puangsombat ${ }^{2}$, Pattawat Seekhaw ${ }^{2}$, Acharaporn $\mathrm{Na}$ Lampang \\ Noenplab $^{3}$ and Jintana Sattayasai ${ }^{1 *}$ \\ ${ }^{1}$ Department of Pharmacology, Faculty of Medicine, Khon Kaen University, Khon Kaen, ${ }^{2}$ Department of Chemistry, Faculty of \\ Science, Chiang Mai University, Chiang Mai, ${ }^{3}$ Phitsanulok Rice Research Center, Wangthong, Phitsanulok, Thailand \\ *For correspondence: Email: sjinta@kku.ac.th; Tel/Fax: 66-43-348397
}

Revised accepted: 7 August 2015

\begin{abstract}
Purpose: To investigate the antioxidative and memory-enhancing effects of aqueous extract of unpolished Thai rice strain of Luem Pua (LP) in SK-N-SH cells and scopolamine-induced memory deficit in mice.

Methods: In SK-N-SH cells, viability was measured by 3-(4,5-dimethylthiazol-2-yl)-2,5diphenyltetrazolium bromide (MTT) assay while intracellular reactive oxygen species (ROS) levels were quantified after pretreatment with $L P(0,200,600$ and $1000 \mu \mathrm{g} / \mathrm{mL})$ in the presence of hydrogen peroxide $\left(\mathrm{H}_{2} \mathrm{O}_{2}\right)$. In mice, memory was impaired by injecting $2 \mathrm{mg} / \mathrm{kg} /$ day scopolamine, for 18 consecutive days. On each day, mice were also force-fed with LP 0, 90 or $180 \mathrm{mg} / \mathrm{kg}$. On the last 5 days of treatment, memory was tested using passive avoidance (PA) and Morris water maze (MWM) tests.

Results: At concentration up to $1,000 \mu \mathrm{g} / \mathrm{mL} L P$ had no effect on SK-N-SH cell viability and significantly reduce intracellular ROS levels of SK-N-SH cells with or without $\mathrm{H}_{2} \mathrm{O}_{2}$. Mice that received 90 or 180 $\mathrm{mg} / \mathrm{kg} L P$ showed a significant decrease in latency time in PA test and an increase in escape latency time in MWM test. These data suggest that $L P$ antagonizes the effect of scopolamine on memory.

Conclusion: LP extract has anti-oxidative and memory-enhancing effects in cell culture and mice. The rice may be a nutraceutical helpful for promoting brain health.
\end{abstract}

Keywords: Dark purple rice, Leum Pua rice, Reactive oxygen species, Memory, Scopolamine, Cell culture

Tropical Journal of Pharmaceutical Research is indexed by Science Citation Index (SciSearch), Scopus, International Pharmaceutical Abstract, Chemical Abstracts, Embase, Index Copernicus, EBSCO, African Index Medicus, JournalSeek, Journal Citation Reports/Science Edition, Directory of Open Access Journals (DOAJ), African Journal Online, Bioline International, Open-J-Gate and Pharmacy Abstracts

\section{INTRODUCTION}

Dementia has a wide range of symptoms associated with a decline in memory or other thinking skills which could reduce a person's ability to perform everyday activities. The most common dementia type is Alzheimer's disease (AD) which accounts for 60 to 80 percent of cases and affects approximately $10-15 \%$ of people older than 65 years [1]. At present, the definite causes of $A D$ remain unknown, and the treatment remains symptomatic without an effective cure. A decrease in acetylcholine in the brains of patients with $A D$, however, appears to be a critical element in producing dementia [2] and the cholinergic neuronal system is the major 
therapeutic rational behind the use of nootropic agents. Scopolamine, a muscarinic cholinergic receptor antagonist, has been widely adopted for studying cognitive deficits in experimental animals [3]. In addition, over the past decade, much attention has been focused on oxidative stress as one of the important mechanisms in $A D$ pathogenesis. Reactive oxygen species (ROS) accumulate in the cells leading to oxidative stress, causing damage to DNA, lipids, proteins and mitochondria that ultimately leads to neuronal death $[4,5]$.

Over the last few decades the influence of diet in protecting neurons against neurodegenerative diseases and enhance cognitive abilities is widely accepted [6]. Recently, previous studies indicate that flavonoid-rich foods such as Camellia sinensis (tea) [7,8], Gingko biloba [911], Theobroma cacao (cocoa) [12-14], and Vaccinium spp. (blueberry) [15-17] improve learning and memory in both young and old animals, and humans [18].

Rice (Oryza sativa) is the most widely consumed staple food for a large part of the world's human population, especially in Asia. Among many varieties of rice, pigmented rice is considered an enriched source of bioflavonoids, and is widely used for therapeutic purposes in traditional and folk medicine. Luem Pua is one of the aromatic and indigenous purple sticky rice, enriched with flavonoids, especially anthocyanins, and have total antioxidant higher than other black rices [19], The present study was aimed to examine the effects of the aqueous extract of Luem Pua rice (LP) in reducing the ROS in SK-N-SH cell cultures and on learning and memory of the animals that were impaired by scopolamine chronic treatment.

\section{EXPERIMENTAL}

\section{Preparation of Leum Pua rice extract (LP)}

The unpolished Thai rice strain of Luem Pua came from Phitsanulok Rice Research Center, Phitsanulok province, Thailand. One kilogram of the rice was crushed into powder and soaked in $1.0 \mathrm{~L}$ distilled water for $24 \mathrm{~h}$ at room temperature with intermittent stirring. After filtration, the same volume of $n$-butanol was added to the aqueous solution. The crude extract was obtained by removal of both solvents using a vacuum evaporator at $50{ }^{\circ} \mathrm{C}$ followed by a high vacuum pumping system. The percent yield of the rice crude extract was 1.97. It was stored in cool tight container and protected from light until required.

\section{Evaluation of cell culture and cell viability}

SK-N-SH human neuroblastoma cells (HTB-11) (ATCC; Manassas, VA) were used in this study and cultured in minimum essential medium (MEM) with supplemented nutrients and essential conditions (GIBCO, Invitrogen Corporation; Grand Island, NY). Cell viability was evaluated by spectrophotometric analysis using MTT (3-(4,5-dimethylthiazolyl-2-yl)-2,5-diphenyltetrazolium bromide) (Sigma-Aldrich; St. Louis, MO). LP was diluted in MEM, added to the cells at final concentrations $0,600,800$ and 1,000 $\mu \mathrm{g} / \mathrm{mL}$, and incubated at $37{ }^{\circ} \mathrm{C}$ for $24 \mathrm{~h}$ after which the MTT solution was added to each well at a final concentration of $500 \mu \mathrm{g} / \mathrm{ml}$. Formazan crystals formed by the living cells were then dissolved in isopropanol and measured at 570 $\mathrm{nm}$ by Multi-Detection microplate reader (BioTek Instruments, Inc.; Winooski, VT).

\section{Determination of intracellular reactive oxygen species (ROS) levels}

Intracellular ROS levels were quantified using 2', 7'-dichlorodihydrofluorescein diacetate (DCFHDA) (Sigma-Aldrich; St. Louis, MO) as previously described [20] with some adaptation. In brief, SKN-SH cells $\left(2 \times 10^{5}\right.$ cells $\left./ \mathrm{mL}\right)$ were incubated with $50 \mu \mathrm{M}$ DCFH-DA at $37^{\circ} \mathrm{C}$ in the dark for 45 min, followed by 45 min incubation with 200,600 or $1,000 \mu \mathrm{g} / \mathrm{mL}$ LP (diluted in MEM). The cells were then treated with 300 or $600 \mu \mathrm{M} \mathrm{H}_{2} \mathrm{O}_{2}$ (Merck Schuchardt OHG, Hohenbrunn, Germany) for $30 \mathrm{~min}$. The fluorescence intensity of DCF was quantified by a Multi-Detection microplate reader at $485 \mathrm{~nm}$ excitation and 530 $\mathrm{nm}$ emission wavelengths.

\section{Scopolamine-induced memory deficits in mice}

Male ICR mice (6 - 8 weeks old, 25-35 g body weight) were purchased from the National Laboratory Animal Center, Mahidol University, Bangkok, Thailand. The animals were kept in an air-conditioned room maintained at $25 \pm 2 \stackrel{\circ}{\circ}$ with a 12:12 h light: dark cycle, with feed and water ad libitum. All animal experiments were performed in accordance with the guidelines of the Animal Ethics Committee, Faculty of Medicine, Khon Kean University, Thailand, record number AEKKU 13/2555 reference number 0514.1.12.2/8.

The animals were divided into 6 groups, 8-10 mice per group. The treatment duration was 18 days. On each day, mice received 2 treatments. Firstly, the animals were force-fed either with distilled water or LP (90 or $180 \mathrm{mg} / \mathrm{kg}$ ). Thirty min 
later, either normal saline or $2 \mathrm{mg} / \mathrm{kg}$ scopolamine were injected intraperitoneally (i.p). Passive avoidance (PA) and Morris water maze (MWM) tests were done on the last 5 days of treatment.

\section{Passive avoidance test}

Passive avoidance, a fear-aggravated test used to evaluate learning and memory in rodents, was done 15 min after the animal received a second treatment on days 14 (training day) and 15 (test day) of treatment. The details of the test have been described earlier [20]. In brief, the apparatus consists of two distinct compartments, light and dark compartments separated by a sliding door. On training day, mouse was placed in the light compartment and allowed to explore for $30 \mathrm{~s}$, at which point the door was opened to allow the mouse enter the dark compartment, and then the door was closed and an electrical foot shock $(0.25 \mathrm{~mA})$ was delivered for $2 \mathrm{~s}$, after that the mouse was removed to its home cage. Test day ( $24 \mathrm{~h}$ after training), the mouse was tested by same protocol as on training day except electrical foot shock was not delivered when the animal entered the dark compartment. The time taken for a mouse to enter the dark compartment after door opening was defined as latency time. Latency time was recorded up to $300 \mathrm{~s}$.

\section{Morris water maze test}

The Morris water maze, a test of spatial learning for rodents, was used at $15 \mathrm{~min}$ after the normal saline or $2 \mathrm{mg} / \mathrm{kg}$ scopolamine injection on days 16, 17 and 18 of treatment [20]. In brief, the Morris water maze consisted of a milky waterfilled circular plastic pool $66 \mathrm{~cm}$ in diameter which was divided into four quadrants of equal areas. A circular platform submerged below the water surface was placed in the center of one quadrant (the target quadrant).

A mouse was trained by placing it on the platform for $1 \mathrm{~min}$ then it was put into the water facing the edge of the pool in the quadrant opposite to the target quadrant, and allowed the maximal time of 1 min for the animal to swim and locate the platform. The time used to locate the platform was expressed as escape latency. If the animal failed to find the platform in $60 \mathrm{~s}$, it was manually guided to the platform and placed on the platform for $15 \mathrm{~s}$. On each day, the tests were performed 3 times with an inter-trial interval of $15 \mathrm{~min}$ [21].

\section{Statistical analysis}

Data were assessed by one-way analysis of variance (ANOVA) and all pairwise multiple comparison procedures (Fisher's LSD method). A $p$-value less than 0.05 were considered as statistically significant.

\section{RESULTS}

\section{In vitro cytotoxicity test and the effects on ROS of LP in SK-N-SH cells}

The results showed that $L P$, at concentrations up to $1000 \mu \mathrm{g} / \mathrm{ml}$, did not affect SK-N-SH cell viability. In addition, the numbers of viable cells were mildly increased after the exposure to LP at 800 and $1,000 \mu \mathrm{g} / \mathrm{mL}$ (Figure 1).

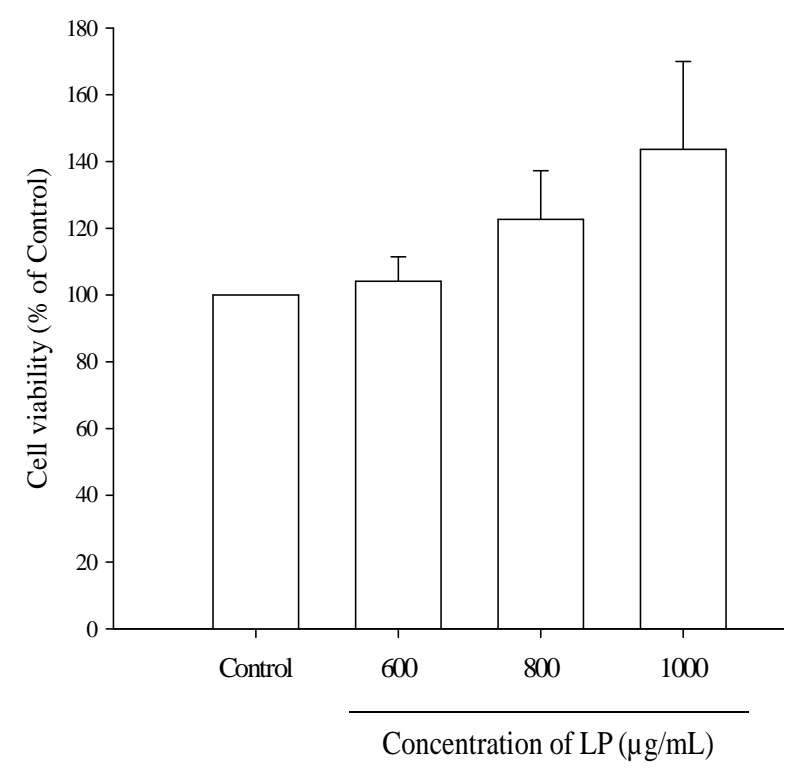

Figure 1: Cytotoxicity screening of Luem Pua rice extract (LP) in SK-N-SH cells. SK-N-SH cells were treated with LP at the concentrations of 600,800 or $1,000 \mu \mathrm{g} / \mathrm{mL}$. After 24-hours of incubation, cytotoxicity was determined by the MTT assay. Data are presented as mean \pm S.E.M.

The cellular oxidative stress was evaluated by measurement of intracellular ROS levels. As shown in Figure 2A, the exposure of SK-N-SH cells to LP 200, 600 and $1000 \mu \mathrm{g} / \mathrm{mL}$ led to a significant decrease of intracellular ROS levels when compared to the untreated cells. Preincubation of SK-N-SH cells with LP at 200, 600 or $1000 \mu \mathrm{g} / \mathrm{mL}$ significantly decreased $\mathrm{H}_{2} \mathrm{O}_{2}$ induced intracellular ROS levels regardless of $\mathrm{H}_{2} \mathrm{O}_{2}$ concentrations (Figure 2B and $2 \mathrm{C}$ ). 


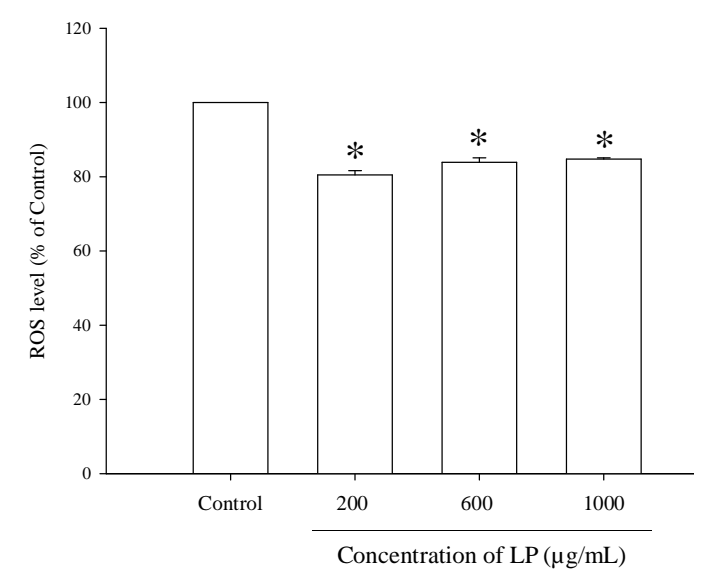

B

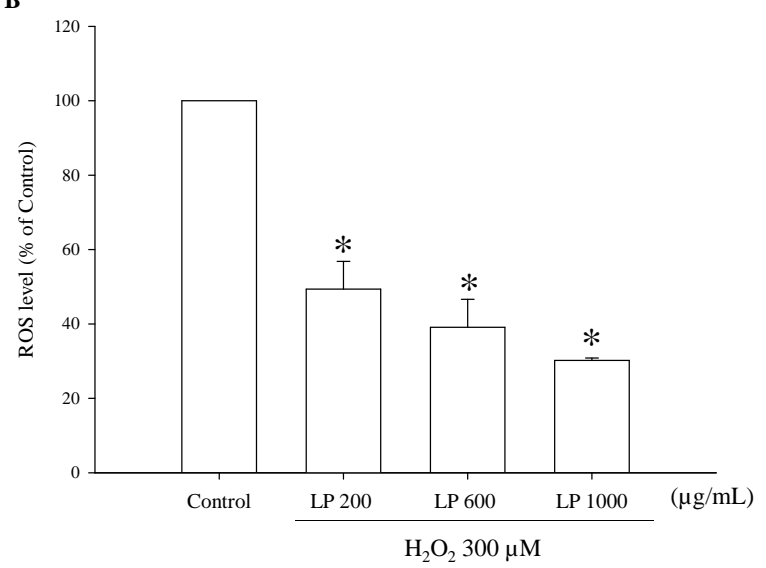

C

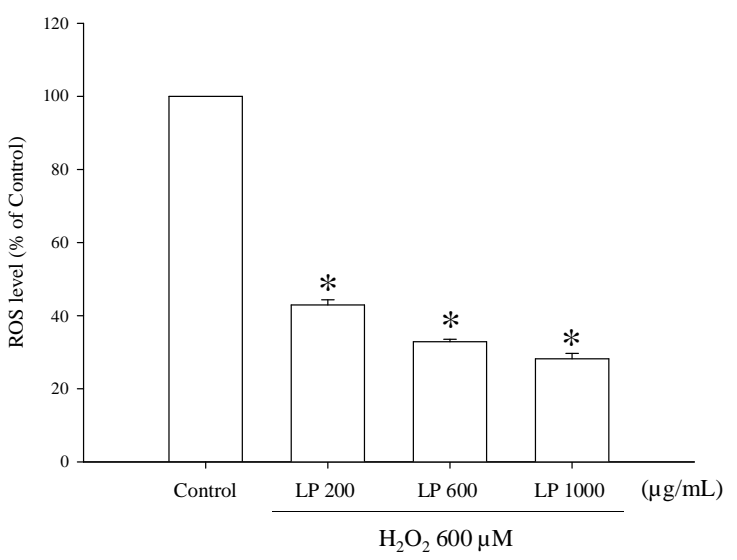

Figure 2: Effects of LP on ROS level in SK-N-SH cells. Cells were preincubated with LP at 200, 600 and $1,000 \mu \mathrm{g} / \mathrm{mL}$, followed by $30 \mathrm{~min}$ incubation with $0 \mu \mathrm{M}$ (A), $300 \mu \mathrm{M}$ (B) or $600 \mu \mathrm{M} \mathrm{H} \mathrm{H}_{2}$ (C). Data are presented as mean \pm S.E.M. ${ }^{*} P<0.05$ compared to the control

\section{Effect of LP on fear memory: Passive avoidance test}

The effects of LP on fear memory are shown in Figure 3. Mice, orally fed with LP 90 or 180 $\mathrm{mg} / \mathrm{kg} /$ day for 15 days, showed a significant increase in percentage change of latency time on the test day when compared to the control (LP0) group, indicating that LP extract could increase learning and memory ability of mice. Animals injected with $2 \mathrm{mg} / \mathrm{kg} /$ day of scopolamine for 15 days showed a significant decrease in percentage change of latency time on test day when compared with the control group. Interestingly, mice that received concomitant 180 $\mathrm{mg} / \mathrm{kg} \mathrm{LP}$ and scopolamine, showed a significant increase in percentage change of latency time when compared with those treated with scopolamine alone, indicating that $180 \mathrm{mg} / \mathrm{kg} \mathrm{LP}$, but not $90 \mathrm{mg} / \mathrm{kg} \mathrm{LP}$, could attenuate scopolamine-induced fear memory impairment.

\section{Morris water maze test}

The effects of LP extract on escape latency of trial 1 are shown in Fig 4. Mice treated with LP at $180 \mathrm{mg} / \mathrm{kg} /$ day showed a significant increase in learning and memory ability as seen by a significant decrease in escape latency time when compared to the control group ( $0 \mathrm{mg} / \mathrm{kg} \mathrm{LP})$ on day 16. On days 17 and 18, every group of animals except the scopolamine-treated group, showed a decreased escape latency time when compared to the same treatment on day 16 . Interestingly, LP extract at doses of 90 and 180 $\mathrm{mg} / \mathrm{kg}$ improved chronic scopolamine treatmentinduced learning and memory impairment. The results of trials 2 and 3 were in the same pattern as trial 1 (data not shown).

\section{DISCUSSION}

This study demonstrated that the aqueous extract of Luem Pua rice (LP) had no effect on viability of SK-N-SH cells. It exhibited significant ROS scavenging properties and provided protection against $\mathrm{H}_{2} \mathrm{O}_{2}$-induced intracellular $\mathrm{ROS}$ in SK-N-SH cells. In the in vivo models, LP produced significant improvement of learning and memory in both passive avoidance and Morris water maze tests. LP also antagonized chronic scopolamine-induced memory deficits.

Scopolamine, a traditional muscarinic receptor antagonist, is widely used as a primary screening test for anti-amnesic drugs [22]. Recently, some studies have demonstrated that memory impairment in the scopolamine-induced animal model is associated with increased oxidative stress within the brain [3,23-25]. In addition, scopolamine treatment also increased biological markers of $A D$ including amyloid beta and tau proteins [26]. As shown in the cell culture 


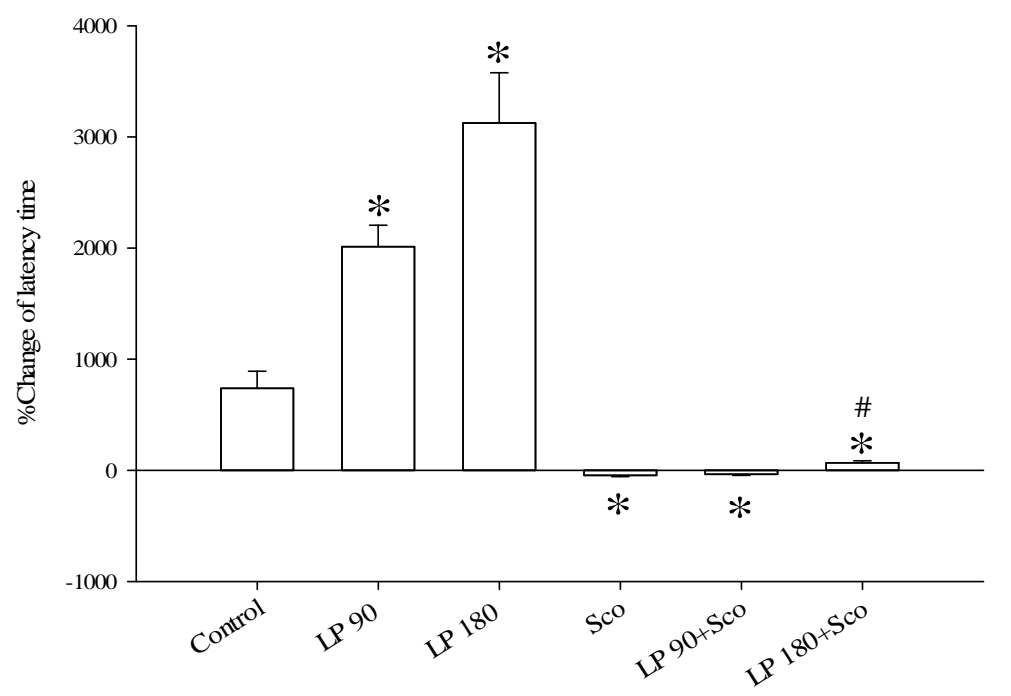

Figure 3: Effects of LP and scopolamine chronic treatment on latency time on the test day in the passive avoidance test are shown. Data are presented as mean \pm SEM. * significantly different when compared to the control group; \# significantly different when compared to the scopolamine-treated group

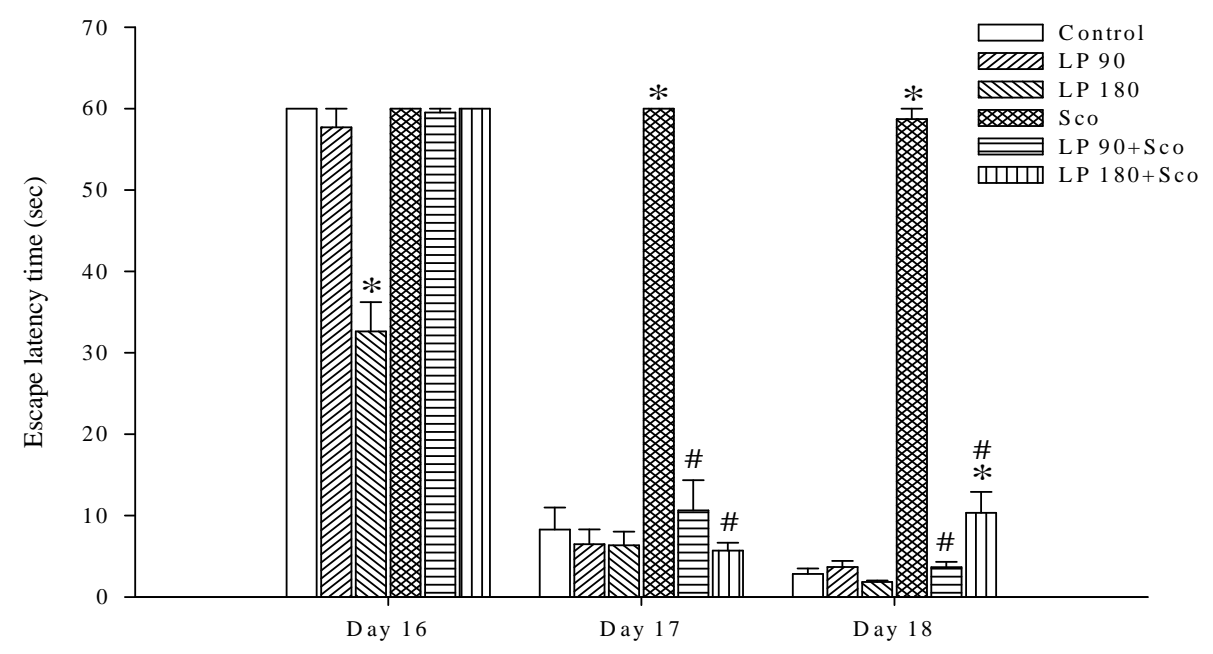

Figure 4: Effects of LP and scopolamine chronic treatment on escape latency time of trial 1, days 16-18 of treatment, in the Morris water maze test. Data are represented as percentage change and presented as mean \pm SEM. * significantly different when compared to the control group; \# significantly different when compared to scopolamine-treated group

experiment, LP extract reversed the effects of scopolamine on memory by reducing the oxidative stress in the brain.

Over the past decades, considerable attention has been focused on the potential of a group of dietary-derived phytochemicals known as flavonoids in modulating neuronal function, thereby increasing memory retention, learning and cognitive functions [27]. In addition, plant flavonoids may delay the development of Alzheimer's disease-like pathology and are suggested to be potential strategies in dementia treatment [28]. Anthocyanins, one of the flavonoid groups predominant in many colored plants, have been credited with capacity to modulate cognitive and motor function, to enhance memory, to prevent age-related declines in neural function [29] and to protect neurons [30]. Luem Pua glutinous rice contains very high anthocyanins, especially in the form of cyanidin-3-glucoside, and high antioxidant activity [19,21]. Although the gastrointestinal absorption of anthocyanins is quite low, they can cross the blood-brain barrier and support antioxidant capacity of the brain and have potential to provide neuro-protection in neurodegenerative conditions [31]. It might be the case 
that the antioxidant activity of the extract was contributing to the memory enhancing effect observed in this study.

\section{CONCLUSION}

LP in cell culture shows a significant ROS reducing effect against $\mathrm{H}_{2} \mathrm{O}_{2}$. The results of the behavior study also suggest that LP has a cognitive enhancing effect. LP also antagonized the deleterious effects of scopolamine on memory. The memory enhancing effect of LP might be through the antioxidant and many other effects of the anthocyanins. This suggests that Luem Pua rice might be developed as a nutraceutical for improving mood and brain function, especially learning and memory.

\section{ACKNOWLEDGEMENT}

This study was supported by research funding from Agricultural Research Development Agency (Public Organization), Thailand. Miss Supawadee Srisuwan was partly supported by Faculty of Medicine, Khon Kaen University, Thailand. We would like to acknowledge Prof James A Will for editing the manuscript via Publication Clinic KKU, Thailand.

\section{REFERENCES}

1. Blennow K, de Leon MJ, Zetterberg H. Alzheimer's disease. Lancet 2006; 368: 387-403.

2. Becker R, Giacobini E, Elble R, Mcllhany M, Sherman K. Potential pharmacotherapy of Alzheimer disease. A comparison of various forms of physostigmine administration. Acta Neurol Scand Suppl 1988; 116: 19-32.

3. Goverdhan P, Sravanthi A, Mamatha T. Neuroprotective effects of meloxicam and selegiline in scopolamineinduced cognitive impairment and oxidative stress. Int J Alzheimers Dis 2012; 2012: 974013. doi: 10.1155/2012/974013. Epub 2012 Mar 22.

4. Bizimenyera ES, Aderogba MA, Eloff JN, Swan GE. Potential of neuroprotective antioxidant-based therapeutics from Peltophorum africanum Sond. (Fabaceae). Afr J Tradit Complement Altern Med 2006; 4: 99-106.

5. Perry G, Cash AD, Smith MA. Alzheimer Disease and Oxidative Stress. J Biomed Biotechnol 2002; 2: 120 123.

6. Gomez-Pinilla F. Brain foods: the effects of nutrients on brain function. Nat Rev Neurosci 2008; 9: 568-578.

7. Kaur T, Pathak CM, Pandhi P, Khanduja KL. Effects of green tea extract on learning, memory, behavior and acetylcholinesterase activity in young and old male rats. Brain Cogn 2008; 67: 25-30.
8. Unno K, Takabayashi F, Yoshida H, Choba D, Fukutomi $R$, Kikunaga $N$, et al. Daily consumption of green tea catechin delays memory regression in aged mice. Biogerontology 2007; 8: 89-95.

9. Oliveira $D R$, Sanada PF, Saragossa Filho AC, Innocenti $L R$, Oler G, Cerutti JM, et al. Neuromodulatory property of standardized extract Ginkgo biloba $L$. (EGb 761) on memory: behavioral and molecular evidence. Brain Res 2009; 1269: 68-89.

10. Shif $O$, Gillette K, Damkaoutis CM, Carrano C, Robbins SJ, Hoffman JR. Effects of Ginkgo biloba administered after spatial learning on water maze and radial arm maze performance in young adult rats. Pharmacol Biochem Behav 2006; 84: 17-25.

11. Williams $B$, Watanabe $C M$, Schultz $P G$, Rimbach $G$, Krucker T. Age-related effects of Ginkgo biloba extract on synaptic plasticity and excitability. Neurobiol Aging 2004; 25: 955-962.

12. Dinges DF. Cocoa flavanols, cerebral blood flow, cognition, and health: going forward. J Cardiovasc Pharmacol 2006; 47 Suppl 2: S221-223.

13. Fisher ND, Sorond FA, Hollenberg NK. Cocoa flavanols and brain perfusion. J Cardiovasc Pharmacol 2006; 47 Suppl 2: S210-214.

14. Francis ST, Head K, Morris PG, Macdonald IA. The effect of flavanol-rich cocoa on the fMRI response to a cognitive task in healthy young people. J Cardiovasc Pharmacol 2006; 47 Suppl 2: S215-220.

15. Krikorian R, Shidler MD, Nash TA, Kalt W, VinqvistTymchuk MR, Shukitt-Hale B, Joseph JA. Blueberry supplementation improves memory in older adults. $J$ Agric Food Chem 2010; 58: 3996-4000.

16. Shukitt-Hale B, Lau FC, Joseph JA. Berry fruit supplementation and the aging brain. $J$ Agric Food Chem 2008; 56: 636-641.

17. Williams CM, El Mohsen MA, Vauzour D, Rendeiro $C$, Butler LT, Ellis JA, Whiteman M, Spencer JP. Blueberry-induced changes in spatial working memory correlate with changes in hippocampal CREB phosphorylation and brain-derived neurotrophic factor (BDNF) levels. Free Radic Biol Med 2008; 45: 295-305.

18. Rendeiro $C$, Vauzour $D$, Kean RJ, Butler $L T$, Rattray $M$, Spencer JP, Williams CM. Blueberry supplementation induces spatial memory improvements and regionspecific regulation of hippocampal BDNF mRNA expression in young rats. Psychopharmacology (Berl) 2012; 223: 319-330.

19. Suwannalert $P$, Rattanachitthawat $S$. High Levels of Phytophenolics and Antioxidant Activities in Oryza Sativa - Unpolished Thai Rice Strain of Luem Phua. Trop J Pharm Res 2011; 10: 431-436.

20. Sattayasai J, Chaonapan $P$, Arkaravichie $T$, SoiAmpornkul R, Junnu S, Charoensilp P, Samer J, Jantaravinid $J$, Masaratana $P$, Suktitipat $B$, et al. Protective effects of mangosteen extract on H2O2induced cytotoxicity in SK-N-SH cells and scopolamine-induced memory impairment in mice.

Trop J Pharm Res, September 2015; 14(9): 1640 
PLoS one 2013;8: e85053. doi: 10.1371/journal.pone.0085053. eCollection 2013.

21. Srisuwan S, Sattayasai J, Arkaravichien T, Wongpornchai S, Luangkamin S, Seekhaw $P, \mathrm{Na}$ Lampang Noenplab A. The Effects of Dark Purple Glutinous Rice Variety Luem Phua on ScopolamineInduced Memory Deficits in Mice. Srinagarind Med J 2013; 28 (suppl): 219-222.

22. Kanwal A, Mehla J, Kunchal M, Naidul VGM, Gupta YK, Sistla R. Anti-amnesic activity of Vitex Negundo in scopolamine induced amnesia in rats. Pharmacol Pharm 2010; 1: 1-8.

23. El-Sherbiny DA, Khalifa AE, Attia AS, Eldenshary Eel D. Hypericum perforatum extract demonstrates antioxidant properties against elevated rat brain oxidative status induced by amnestic dose of scopolamine. Pharmacol Biochem Behav 2003; 76 : 525-533.

24. Fan Y, Hu J, Li J, Yang Z, Xin X, Wang J, Ding J, Geng $M$.. Effect of acidic oligosaccharide sugar chain on scopolamine-induced memory impairment in rats and its related mechanisms. Neurosci Lett 2005; 374: 222-226.

25. Jeong EJ, Lee KY, Kim SH, Sung SH, Kim YC. Cognitiveenhancing and antioxidant activities of iridoid glycosides from Scrophularia buergeriana in scopolamine-treated mice. Eur J Pharmacol 2008; 588: 78-84.

26. Bihaqi SW, Singh AP, Tiwari $M$. Supplementation of Convolvulus pluricaulis attenuates scopolamineinduced increased tau and amyloid precursor protein (AbetaPP) expression in rat brain. Indian $J$ Pharmacol 2012; 44: 593-598.

27. Rendeiro C, Guerreiro JD, Williams CM, Spencer JP. Flavonoids as modulators of memory and learning: molecular interactions resulting in behavioural effects. The Proc Nutr Soc 2012; 71: 246-262.

28. Vauzour $D$. Effect of flavonoids on learning, memory and neurocognitive performance: relevance and potential implications for Alzheimer's disease pathophysiology. J Sci Food Agric 2014; 94: 1042-1056.

29. Lila MA. Anthocyanins and human health: an in vitro investigative approach. J Biomed Biotechnol. 2004; 5: 306-313.

30. Kelsey NA, Wilkins HM, Linseman DA. Nutraceutical antioxidants as novel neuroprotective agents. Molecules 2010; 15: 7792-7814.

31. Rashid K, Wachira FN, Nyariki JN, Isaac AO. Kenyan purple tea anthocyanins and coenzyme-Q10 ameliorate post treatment reactive encephalopathy associated with cerebral human African trypanosomiasis in murine model. Parasitol Int 2014; 63: 417-426. 